\title{
Cefepime Hydrochloride
}

National Cancer Institute

\section{Source}

National Cancer Institute. Cefepime Hydrochloride. NCI Thesaurus. Code C1041.

The hydrochloride salt of a semi-synthetic, beta-lactamase-resistant, fourth-generation cephalosporin antibiotic derived from an Acremonium fungal species with broadspectrum bactericidal activity. Administered parenterally, cefepime inhibits bacterial cell wall synthesis by binding to and inactivating penicillin-binding proteins (PBP) located on the inner membrane of the bacterial cell wall. Inactivation of PBPs interferes with the cross-linkage of peptidoglycan chains necessary for bacterial cell wall strength and rigidity, resulting in a reduction of bacterial cell wall stability and cell lysis. This agent is more active ag ainst a variety of Gram-positive pathogens compared to third-generation cephalosporins. 